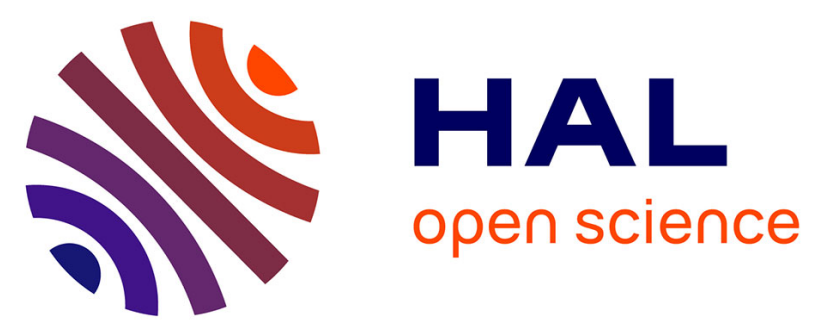

\title{
Taxonomic addition to the early diverged parasitic wasps (Hymenoptera: Orussoidea) from the mid-Cretaceous Burmese amber
}

Corentin Jouault, Vincent Perrichot, André Nel

\section{- To cite this version:}

Corentin Jouault, Vincent Perrichot, André Nel. Taxonomic addition to the early diverged parasitic wasps (Hymenoptera: Orussoidea) from the mid-Cretaceous Burmese amber. Proceedings of the Geologists' Association, 2021, 132 (3), pp.324-331. 10.1016/j.pgeola.2021.02.002 . insu-03203872

\section{HAL Id: insu-03203872 \\ https://hal-insu.archives-ouvertes.fr/insu-03203872}

Submitted on 21 May 2021

HAL is a multi-disciplinary open access archive for the deposit and dissemination of scientific research documents, whether they are published or not. The documents may come from teaching and research institutions in France or abroad, or from public or private research centers.
L'archive ouverte pluridisciplinaire $\mathbf{H A L}$, est destinée au dépôt et à la diffusion de documents scientifiques de niveau recherche, publiés ou non, émanant des établissements d'enseignement et de recherche français ou étrangers, des laboratoires publics ou privés. 
Taxonomic addition to the early diverged parasitic wasps (Hymenoptera: Orussoidea) from the midCretaceous Burmese amber

CORENTIN JOUAULT ${ }^{1, *}$, VINCENT PERRICHOT ${ }^{1}$, ANDRE NEL ${ }^{2}$

1Univ Rennes, CNRS, Geosciences Rennes, UMR 6118, F-35000, Rennes, France. E-mail: jouaultc0@gmail.com; orcid.org/0000-0002-3680-5172 / vincent.perrichot@univ-rennes1.fr; https://orcid.org/0000-0002-7973-0430

Institut de Systématique, Évolution, Biodiversité (ISYEB) Muséum national d'Histoire naturelle, CNRS, Sorbonne Université, EPHE, Université des Antilles, CP50, 57 rue Cuvier 75005 Paris, France. E-mail: anel@mnhn.fr; orcid.org/0000-0002-4241-7651

*corresponding author

\begin{abstract}
A new genus and species of orussoid wasps, Cretorussus vilhelmseni gen. et sp. nov., is described based on new material from the mid-Cretaceous Burmese amber. Its wing venation and body characters lead us to emend the diagnosis of the family Burmorussidae. Cretorussus vilhelmseni gen. et sp. nov. is considered to be a specialized parasitic wasp of wood-living hosts because of the orussidlike ocellar crown, antennae attached well above clypeus, and antennal grooves absent. Interestingly, the third tarsomere carries a prominent lanceolate lobe, serving as part of the host detection. We propose a summary of the orussoid fossil diversity. Lastly, we discuss the implications of several characters of Burmorussidae and that are involved in host detection.
\end{abstract}

Key words. Insecta; 'Symphyta'; Mesozoic; Burmorussidae; parasitic wasps 


\section{Introduction}

'Symphyta', also called 'sawflies' due to the saw-like appearance of their ovipositor (although orussids and siricids have cylindrical ovipositors with teeth at the tip, more drill-like than saw-like), is a paraphyletic grade of Hymenoptera (e.g. Ronquist et al., 2012; Ma et al., 2019), easily recognizable thanks to the lack of 'wasp waist' on adults (e.g. Rasnitsyn, 1968, 1969; Goulet \& Huber, 1993). The fossil record of 'Symphyta' is of particular importance for calibrating the time divergence estimate of Hymenoptera (Ronquist et al., 2012) but also to analyze the transition from Symphyta to Apocrita. Recent studies estimated that Hymenoptera, and therefore 'Symphyta', arose during the Carboniferous or Permian (e.g. Ronquist et al., 2012; Peters et al., 2017), in accordance with the description of a stem group representative from the Late Carboniferous (Nel et al., 2013). Currently, oldest occurrences of the crown group Hymenoptera are known from the Middle Triassic (e.g. Rasnitsyn, 1964; Kopylov, 2014; Oyama et al., 2020), while the first Orussoidea appear in the Middle Jurassic, from the Callovian / Oxfordian formation of Karabastau (see Table 1). The peculiar origin of 'Symphyta' makes this group a good choice to estimate the impact of the Permo-Triassic crisis on the radiation of Hymenoptera. The superfamily Orussoidea, including Orussidae Newman, 1834, Paroryssidae Martynov, 1925, and Burmorussidae Zhang, Kopylov \& Rasnitsyn, 2020, is assumed to arise during the Permian to Triassic period (see references above), and it occupies a sister lineage position with respect to the Apocrita (e.g. Ronquist et al., 1999; Vilhelmsen, 2001; Ronquist et al., 2012; Ma et al., 2019; Zhang et al., 2020).

Therefore, orussoid wasps are key to understanding the transition to parasitic behavior since the latter arises in the common ancestor of Orussidae and Apocrita (Vilhelmsen \& Turrisi, 2011). However, the orussoid fossil record is too poor for a good estimate of their extinct diversity (Table 1), contrary to many symphytan lineages with many species known from fossil imprints (e.g., gen- 
eral catalog: Taeger et al. 2010; Xyeloidea: Oyama and Maeda 2020; Siricoidea: Jouault et al. 2020a; Tenthredinoidea: Nel et al., 2004; Pamphilioidea: Wang et al. 2016; Cephoidea: Kopylov \& Rasnitsyn 2016).

Herein we describe a new mid-Cretaceous orussoid wasp based on a female specimen embedded in Burmese amber from Noije Bum deposit. It is the second record of this superfamily in this amber (Zhang et al., 2020).

\section{Material and methods}

The specimen studied herein derives from the deposits of Noije Bum in the Hukawng Valley $\left(26^{\circ} 29^{\prime} \mathrm{N}, 96^{\circ} 35^{\prime} \mathrm{E}\right)$, Kachin State, northern Myanmar (see detailed map in Grimaldi \& Ross 2017: fig. 2). Radiometric data established an early Cenomanian age (98.79 $\pm 0.62 \mathrm{Ma})$ for Kachin amber, based on zircons from volcanic clasts found within the amber-bearing sediments (Shi et al. 2012). Some ammonites found in the amber-bearing bed and within amber corroborate a late Albian-early Cenomanian age (Cruickshank \& Ko 2003; Yu et al. 2019).

The amber piece was polished to facilitate the examination of the specimen using a grinder polisher (Buehler EcoMet 30) and very thin silicon carbide sanding paper (grit size $=7000$ ) or a diamond disk. The specimen was examined and photographed with a Leica MZ APO and a Canon EOS 5D Mark II camera. All images were digitally stacked photomicrographic composites of several individual focal planes, which were obtained using HeliconFocus 6.7. The figures and drawings were composed with Adobe Illustrator CC2019 and Photoshop CC2019 softwares. The type specimen is housed in the amber collection of the Geological Department and Museum (IGR) of the University of Rennes (France), under the collection number IGR.BU-020.

Published work and nomenclatural acts are registered in ZooBank (http:// www.zoobank.org/, last access: 22 February 2021), with the following LSID (reference): urn:lsid:zoobank.org:pub:C7503E44-8261-4896-8FA1-13D637C079FD 


\section{Systematic Paleontology}

Order Hymenoptera Linnaeus, 1758

Suborder Symphyta Gerstaecker, 1867

Superfamily Orussoidea Newman, 1834

Family Burmorussidae Zhang, Kopylov \& Rasnitsyn, 2020 (in Zhang et al., 2020)

Included genera: Type genus Burmorussus Zhang, Kopylov \& Rasnitsyn, 2020 (in Zhang et al., 2020) and Cretorussus gen. nov.

Emended diagnosis. Head with crown of paired backward-pointing teeth around median ocellus (ocellar corona) with ventral-most coronal teeth well below median ocellus, ventral unpaired tooth absent. Eyes large, occupying major part of head surface. Antennae with 10 to 12 flagellomeres, attached above clypeus, near mid-height of eye (a character infrequent among the Hymenoptera; see Zhang et al., 2020: matrix of characters). Ventral transverse frontal carina and antennal grooves absent. Mandibles projected, with tips meeting anteriorly of labrum. Mesonotum with median mesoscutal sulcus, parapsidal lines, and transscutal line well developed; notauli weak, converging, vanishing in the middle of mesonotum, reaching neither each other nor mesoscutal sulcus nor transscutal line. Middle and hind coxae separated by elongated postepisternum. Fore wing with crossveins $1 \mathrm{r}-$ rs, 2r-rs, 2r-m, 1m-cu, 2m-cu, 1cu-a, 2cu-a and a1-a2 developed, 3r-m lost; 1r-rs shorter or subequal to 2r-rs; 2A well developed beyond a1-a2 and partly spectralized basad of a1-a2; 3A absent; wing fixation apparatus (cenchri + rough area within anal loop) not developed (after Zhang et al., 2020). Hind wing with cell R1 enclosed; crossveins 1r-m and cu-a present, 2r-m and m-cu lost. 1 st abdominal segment flat dorsally, not divided medially, differing in shape and surface sculpture from subsequent segments, 'forming a kind of propodeum, not fused laterally with metapleura' after Zhang et al. (2020: 596), although these authors indicated in their matrix of characters that they 
cannot decide about its fusion with the metapleuron; articulation between 1st and 2nd abdominal segments (propodeum and 1st metasomal) flexible, waist between 1st and 2nd segments wide in dorsal view and not deep in side view.

Genus Cretorussus gen. nov.

urn:1sid:zoobank.org:act:508F27EC-6FC9-42A5-BD14-5434A5F5695E

Etymology: The new genus-group name combines the Latin creta, chalk, used here in reference to the Cretaceous period, and the genus Orussus Latreille, 1796 (type genus of the Orussoidea). Gender masculine.

Type species. Cretorussus vilhelmseni sp. nov. (only species included).

Diagnosis. Antennae with 10 flagellomeres, attached high above clypeus, before mid-height of eye, three pre-apical flagellomeres wider than others, flagellomeres I (FI) and 2 (FII) conspicuously longer than remaining ones. Mesonotum with median mesoscutal sulcus, notauli, parapsidal lines, transscutal line developed (hard to compare with Burmorussus). Fore wing with the pterostigma long and thin; veins 1-Rs nearly twice as long as 1-M, 3-Rs and 4-Rs sub-equal, 3-M and 4-M aligned, 2A with concavity oriented posteriorly; crossveins 1r-rs and 2r-rs subequal, 2m-cu tubular.

Cretorussus vilhelmseni sp. nov.

Figures 1-3

urn:Isid:zoobank.org:act:A02319DB-45F0-4666-BD67-6D8376FB8EDD

Etymology. The specific epithet honors Dr. Lars Vilhelmsen for his outstanding contributions to the knowledge of Orussidae, and it is to be treated as a noun in a genitive case.

Material. Holotype IGR.BU-020 (a specimen preserved in a rectangular piece of amber measuring 7 $\times 11 \times 3 \mathrm{~mm})$. 
Locality and horizon: Noije Bum Hill, Hukawng Valley, Kachin State, Myanmar; upper Albian to lower Cenomanian, mid-Cretaceous.

Description. Female (?), body as preserved $2.80 \mathrm{~mm}$ long. Head nearly as wide as high (1.08 $\mathrm{mm}$ high and $1.04 \mathrm{~mm}$ wide), roughly dotted; eyes, $0.81 \mathrm{~mm}$ high and $0.53 \mathrm{~mm}$ wide (in side view) ca. $0.75 \times$ head height; ocelli slightly ovoid with lateral ones slightly wider than median one, distance between ocelli about twice as long as ocellar width; ocellar corona consisting of 5-6 pairs of tubercles, with upper tubercles overlapping and forming irregular transverse ridges between lateral ocelli. Antenna $2.53 \mathrm{~mm}$ long, geniculate, with 10 flagellomeres; scape $0.39 \mathrm{~mm}$ long and $0.12 \mathrm{~mm}$ wide, robust, $3.25 \times$ longer than wide and $0.48 \times$ eye height, and ca. $0.15 \times$ antennal length; pedicel short $0.16 \mathrm{~mm}$ long and $0.07 \mathrm{~mm}$ wide, cylindrical, more than twice as long as wide, $0.41 \times$ scape; flagellum widening toward apex; lengths of flagellomeres (in mm): FI 0.35, FII 0.33, FIII 0.16, FIV 0.24, FV-VI 0.16, FVII-VIII 0.12, FIX 0.13, FX 0.11; 1st flagellomere 2.19× as long as pedicel and about $7 \times$ longer than wide, 2 nd $0.95 \times$ as long as 1 st, following ones gradually decreasing in length but increasing in width, apical one about twice as long as wide, rounded apically. Clypeus with sparse setae along anterior margin. Mandibles slightly protecting anteriorly, with three teeth: one obtuse tooth on upper edge of mandible and two sharp teeth on tip. Maxillary palpi five-segmented with basal palpomere the longest, labial palpi not clearly visible.

Thorax roughly dotted, with irregular transverse sculpture. Mesepisternum conspicuously dotted. Mesonotum with median mesoscutal sulcus deeply impressed; parapsidal and transscutal lines developed; notauli weak, converging, vanishing in the middle of mesonotum, reaching neither each other nor mesoscutellar sulcus or transscutal line. Axilla triangular, with portion near median mesoscutal sulcus not well defined. First pair of legs fully preserved with procoxae ca. $0.34 \mathrm{~mm}$ long, femora about $0.81 \mathrm{~mm}$ long, tibia about $0.69 \mathrm{~mm}$ long, conspicuously swollen after midlength, protibial spurs stout and apically bifid. Protarsus five-segmented, third tarsomere with lanceolate ventral apophysis; fourth tarsomere very short, length of protarsomeres combined ca. 0.5 
mm. Mid-legs destroyed. Left hind leg partially preserved with tibia swollen. Tarsal claws, with a basal tooth. Arolium present.

Fore wing at least $3.30 \mathrm{~mm}$ long, with costal space widening toward pterostigma; pterostigma completely sclerotized, long and thin (nearly parallel sides); costal vein C overlapping base of pterostigma, costal flexion line oblique; 1-Rs $1.76 \times$ longer than $1-\mathrm{M}$; Rs $+\mathrm{M}$ short, $0.40 \times$ as long as 1-Rs; 2-Rs slightly longer than 1r-rs (1.2× longer); 4-Rs slightly shorter than 3-Rs (about $0.85 \times)$; 1r-rs slightly angled, joining pterostigma in its first quarter; $2 \mathrm{r}$-rs tubular, vertical, sub-equal to $1 \mathrm{r}-$ rs, joining pterostigma after its mid-length; cell $1 \mathrm{R} 1$ about $1.34 \times$ as long as wide; $2 \mathrm{R} 1$ about $1.58 \times$ longer than wide; 3R1 conspicuously longer than wide but not measurable due to preservation; 2-M $1.25 \times$ longer than Rs+M; 3-M about $1.46 \times$ longer than 2-M; cell Rs $1.34 \times$ longer than wide; 2-rm slightly curved medially; $2 \mathrm{~m}$-cu tubular; $2-\mathrm{Cu} 1.57 \times$ longer than $1-\mathrm{Cu}$; cell $1 \mathrm{M} 1.33 \times$ as long as wide; 2-1A preserved but 3-1A not fully preserved; cell 2A present; veins 2-Rs, 3-M, 2r-m, 1cu-a and $2 \mathrm{cu}-\mathrm{a}(?)$ each with one bulla in their lower part, while $2 \mathrm{~m}$-cu has one bulla in its apical part; $1 \mathrm{~A}$ not developed beyond 2A cell; 3-1A not preserved; a1-a2 preserved but separate from remaining part of wing by a break in amber matrix; $2 \mathrm{~A}$ preserved as a short stem with a concavity directed toward wing posterior margin. Hind wing partially preserved, $\mathrm{C}$ and $\mathrm{R}$ separated by a conspicuous costal space slightly widening toward apex; $\mathrm{C}$ with basal hamuli if present not preserved; at least two median and seven distal hamuli present; cell R1 about $4.75 \times$ longer than wide; 1 -Rs proclined; 1r-m partially preserved. 1st abdominal segment (propodeum) coarsely dotted, subsequent segments not preserved.

\section{Discussion}

\subsection{Systematic placement}

Recently, the family Burmorussidae was created based on Burmese amber fossils (Zhang et al., 2020), emending the diagnosis of the superfamily Orussoidea. Based on this recent modifica- 
tion, we assign our new specimen to the Orussoidea because of the absence of vein 3r-m and of tubular vein $\mathrm{A} 2+3$ on the fore wing (vs. present in Karatavitoidea). It also differs from the karatavitoids by an enlarged scape. Cretorussus gen. nov. differs from the Siricina $(=$ Symphyta $\mathrm{s}$. str. $=$ Symphyta except Orussoidea) by the first abdominal segment which is not subdivided medially, and the fore wing with Sc absent (e.g. Rasnitsyn \& Zhang, 2010; Jouault et al., 2020a: fig. 3). It also differs from the Apocrita (= Vespina excluding Orussoidea and Karatavitoidea) by the propodeum and metapostnotum separated from the metapleura laterally, the lack of a true wasp waist, and a more developed fore wing venation (e.g. with 1r-rs cross-vein present). However, our specimen does not perfectly fit with the recent diagnosis of Orussoidea (Zhang et al. 2020: 2) since it possesses a tubular vein $2 \mathrm{~m}-\mathrm{cu}$.

At present, the superfamily Orussoidea comprises the three families Orussidae, Paroryssidae, and Burmorussidae (Zhang et al., 2020). Our specimen cannot be assigned to the Orussidae based on the number of flagellomeres, viz. nine flagellomeres in males and eight in females in extant orussids (vs. 10 in our specimen), and the more developed wing venation (cross vein 1r-rs and $2 \mathrm{~m}$-cu present and tubular). It also differs from the Paroryssidae by the presence of an ocellar corona (vs. lacking), the antennae with 10 flagellomeres (vs. more than 14), and the enlarged scape (vs. not enlarged).

The fossil record of male Orussoidea is sparse, known only from Minyorussus Basibuyuk et al., 2000 (Cretaceous) and Baltorussus Schedl, 2011 (Eocene), both with nine flagellomeres, while female Mesorussus Rasnitsyn, 1977 (Upper Cretaceous) have ten flagellomeres (Vilhelmsen, 2004). The long, enlarged, robust scape of Cretorussus gen. nov. is also a remarkable feature among the Orussoidea.

The only orussoid family known from the Burmese amber is Burmorussidae. Cretorussus gen. nov. differs, at least, from the diagnosis of the Burmorussidae, and therefore from Burmorussus (Zhang et al., 2020), by its antennae with 10 flagellomeres (vs. 12), attached below mid-height of 
the eye (vs. at mid-height of the eye), and FI and FII conspicuously longer than the rest; the mesonotum with median mesoscutal sulcus, notauli, parapsidal and transscutal lines developed (difficult to compare, not well-preserved in Burmorussus); the fore wing with crossveins 2r-rs and 2mcu tubular (vs. spectral in Burmorussus), 1r-rs sub-equal to 2r-rs, and 3-Rs sub-equal to 4-Rs.

Interestingly Cretorussus gen. nov. possesses a complete median mesoscutal sulcus while all the crown-Orussidae, except Baltorussus (see Vilhelmsen \& Zimmermann, 2014), lack this character.

\subsection{Sex differentiation and characters implications in Burmorussidae}

The apical part of the abdomen of our specimen is not preserved. Therefore, we cannot observe the ovipositor or the spiracle arrangement inside the abdomen. In order to deduce the sex of the specimen, we assume that the female Burmorussidae and Orussidae shared similar specialized structures involved in host detection. In fact, female orussid wasps possess a prominent lanceolate lobe on the first tarsomere (distal flange) used in vibration for host detection; this is also recorded in stephanid females and males (Vilhelmsen et al. 2001, 2008; Vilhelmsen \& Turrisi 2011). This character is observed in Burmorussus and Cretorussus gen. nov. and may suggests that they are both females, except that at least in Cretorussus gen. nov., the flange is on the third basitarsomere.

Additionally, we stated that the tarsomere number used to separate the extant male and female Orussidae does not apply for fossil (Nel, 1997). The state 'five tarsomeres' is a ground plan feature/synapomorphy of Insecta. It is very likely that the orussid female fore 'basitarsomere', longer than the two remaining tarsomeres, is in fact a composite structure, resulting from fusion of the fore tarsomeres 1-3 of the males (Vilhelmsen et al., 2001: 78). If Cretorussus gen. nov. and Burmorussus specimens are indeed females, this would support the hypothesis of fusion. This putative fusion in the fore leg of female orussids could serve to facilitate the transmission of vibrations between wood and the tibial enlarged subgenual organ (SGO) as there is no 'break' of membranous 
tissue to 'negotiate' along the way (L. Vilhelmsen pers. comm.). Therefore, it is likely that both females and males of Burmorussidae had five tarsomeres (a plesiomorphic state of character). These observations suggest that our specimen may be female displaying the plesiomorphic state of tarsomeres.

Zhang et al. (2020) also assumed that their specimens were males owing to the lack of modified apical part of the antenna seen in orussid females. Indeed, in orussid females the last flagellomeres are transformed into strongly sclerotized 'mallets', used to produce sound waves inside the wood. The extant orussid males are not involved in host-seeking activities and therefore do not need modification of their antennae and legs for the vibration sense. But the absence of this 'sonar' is clearly a plesiomorphy. The Burmorussidae females may have displayed this plesiomorphic, unmodified antennae, so that we cannot ascribe the male sex to the type specimens of Burmorussus and Cretorussus gen. nov. based solely on the absence of this character

Another striking character of our new genus is the modified fore tibia which is distally swollen and subdivided medially by a groove. This character is also typical of orussid females (Vilhelmsen, 2003: 385) where the furrow marks the proximal limits with the comparatively thinner part of the wall of the distal tibia, which presumably serves to transmit vibrations from the fore basitarsus to the tibial SGO, filling up a large portion of the distal part of the tibia in the female (Vilhelmsen et al. 2001). In Cretorussus gen. nov., the furrow is located near the mid-length of the fore tibia, forming a clear longitudinal groove. We assume that both organizations and structures are similarly involved in host location and vibration transmission. Recording this character in the holotype of Cretorussus gen. nov. also strengthens its attribution as a female. In Burmorussus, the fore and mid tibiae are thin while the hind tibia is inflated and may contain a sensory organ (Zhang et al., 2020). Therefore, there is a difference in the modification of the fore tibia which may strengthen the attribution of Zhang et al. (2020) as a male. 
Additionally, the tibia of Cretorussus gen. nov. bears conspicuous spines which may probably push against the sides of the tunnel together with the other legs and the ocellar corona, to help the mandibles to hang in the wood when gnawing through the later to escape from the pupal chamber.

The differentiation between male and female can also be made based on the presence of the ovipositor. However, in extant orussid females the latter can be very narrow or inverted inside the abdomen (e.g. Vilhelmsen et al., 2001; Vilhelmsen, 2016: fig. 5b; Vilhelmsen et al., 2017: fig. 4a; Vilhelmsen, 2020), suggesting that it may be present but invisible in the holotype of Burmorussus. However, the metasomal apex of Burmorussus is not modified to shelter an internalized ovipositor (viz. metasomal apex is externally simple and somewhat depressed vs. high in females of Orussidae), which suggests that the specimen of Burmorussus described by Zhang et al. (2020) is a male.

All these similarities between the holotypes of Burmorussus and Cretorussus gen. nov. challenge their placement and the delineation of female and male characters. We suggest that the presence/absence of lobe on the fore tarsomere plus the absence of modification and medial groove on the fore tibia could be used to determine the sex of fossil burmorussids as female or male, respectively.

Extant orussid wasps are ectoparasitic of Buprestidae (Coleoptera), Cerambycidae (Coleoptera), Siricidae, and Xiphydriidae (Hymenoptera) (e.g. Burke, 1917; Rawlings, 1957; Powell \& Turner, 1975; Nutall, 1980; Vilhelmsen et al., 2001). The descriptions of Qitianniu zhihaoi Lin \& Bai, 2017 (Cerambycidae) and Acmaeodera burmitina Cockerell, 1917 (Elateriformia) from the mid-Cretaceous Burmese amber biota, may suggest that the Burmorussidae and the extant Orussidae shared similar hosts. Unfortunately, large Siricidae are unlikely trapped in amber since the latter entombed mostly small insects. Similarly, the family Xiphydriidae is today unknown from the Burmese amber biota. However, the family Anaxyelidae is present in Burmese amber (Wang et al., 2020) and may be a good host candidate for the Burmorussidae. 
Most representatives of the superfamily Orussoidea (except Paroryssidae) share with the Stephanidae Leach, 1815 and the Ohlhoffiidae Jouault et al., 2020b a crown of backward-pointing teeth around the median ocellus (ocellar corona), a character that may be considered as a convergent response to similar behaviors of exploring wood-boring galleries or to the same constraint of leaving the galleries dug by their hosts (Vilhelmsen \& Turrisi 2011). If the distribution of the teeth composing the crown differs between stephanoid and orussoid wasps (a single, median, anterior tooth present in Stephanidae vs. a pair of ventral teeth or no tooth in Orussoidea), they are probably involved in similar function: allowing the insect to progress in the galleries or to leave the pupal chamber by tilting movement of the head (anchoring these teeth in the ceiling, and serving to brace the head in position against the action of the mandibles). The polarity and implications of these characters (viz. ocellar corona) are hard to define since only observed in few wasp lineages, and also challenging to observe in fossils preserved as rock imprints (e.g. Paroryssidae). However, two phylogenetic hypotheses have been proposed to determine the origin of the ocellar corona (Vilhelmsen \& Turrisi, 2011; Zhang et al., 2020): firstly, a common origin for Orussoidea and Apocrita inherited from their common ancestor and subsequently lost in derived groups; secondly, independent acquisitions within the two clades by evolutionary convergence. The latter statement is supported by the absence of ocellar corona in many fossil taxa intermediate to both lineages (e.g. Paroryssidae), also their absence in most non-aculeate Apocrita, and finally the different configurations recorded in the Orussoidea and in the Stephanidae or other Apocrita (e.g. Baissidae, Andreneliidae). We assume that both lineages have acquired them independently. Additionally, the ocellar corona of Cretorussus gen. nov. is composed of less acute teeth than in other orussoid genera. The transition from a head apparently lacking an ocellar corona (e.g. Karavitidae) to the Orussidae with conspicuous teeth may have involved several transitional stages in the configuration and in the shape of the teeth composing the corona. The ocellar corona was possibly at the first stage composed of a reduced number of teeth not fully developed and then has evolved to sharp teeth under selection pres- 
sures. The fact that it is 'worn down' in our specimen of Cretorussus gen. nov. may strengthen the placement of Burmorussidae as an early diverged family among the Orussoidea (Zhang et al., 2020: fig. 3) since Cretorussus gen. nov. may display an ocellar corona close to that of the putative orussoid ancestor (viz. with blunt teeth). Interestingly, the ocellar corona of Cretorussus gen. nov. is composed of paired teeth between and in front of the posterior ocelli. The two dorsalmost pairs are fused in a ridge which may represent the plesiomorphic state of the ocellar corona since this character is shared with the early diverged extant orussid taxa (e.g. Leptorussus; Vilhelmsen, 2003: fig. 107), suggesting that the clear delineation between the teeth composing the ocellar corona was acquired later during the evolutive history of Orussoidea.

Antennal grooves are involved in the protection of fragile antennae while moving through boring galleries (Vilhelmsen \& Turrisi 2011). Cretorussus gen. nov. has robust antennae that may 'need' no protection, resulting in the absence of a groove. Moreover, the antennal groove is not a ground plan feature of crown-Orussidae, but evolved within the family (Vilhelmsen 2003; Vilhelmsen \& Zimmermann 2014). Therefore, Rasnitorussus displays the plesiomorphic character state for the family. The more dorsal insertion of the antennae in Burmorussidae (in particular Burmorussus) might make them less likely to evolve a ventral antennal groove. The different organization of the groove suggests a divergence point between the families: adults that have not yet emerged from their cocoons have their antennae lying below the body in Orussidae, while organization of the burmorussid head suggests their antennae were lying above the body. As for Burmorussus, the scape of Cretorussus gen. nov. coincides with the space existing between the prominent eye and the raised frons. This space may replace the groove, serving as a substitute.

\section{Conclusion}

The description of Cretorussus vilhelmseni gen. et sp. nov. extends the diversity and knowledge on burmorussid wasps in Burmese amber biota. With its wing venation slightly more devel- 
oped than in Burmorussus, the veins 2r-rs and 2m-cu being tubular and fully developed, Cretorussus gen. nov. should therefore occupy a position of early diverged taxa within the Burmorussidae and among the Orussoidea. The discovery of additional specimens of Cretorussus gen. nov. should allow the observation of complementary wing venation characters and help to clarify the 'transition' from Karatavitoidea to Orussoidea. It is also important to investigate other fossil deposits to discover additional specimens from the Triassic period corresponding to the putative origin of the superfamily. Finally, the more complete will be the orussoid fossil record, the better we will understand the transition to the parasitic way of life.

Interestingly, our burmorussid female retains plesiomorphic character states (viz. tarsomeres unfused, antenna unmodified, etc.) but shares with extant Orussidae some specialized structures involved in host detection. However, the evidence for the sex determination of the fossils is still somewhat underwhelming and the discovery of an undisputed female specimen with exerted ovipositor will greatly help understanding the implications of the characters discussed above and clarify the burmorussid sexual dimorphism.

\section{Acknowledgment}

We thank Thibault Ramage for checking the tarsomere state of some extant orussid wasps. We are grateful to Dr. Lars Vilhelmsen and Prof. Alexandr P. Rasnitsyn for the insightful corrections and comments provided on the early version of the manuscript. We thank Malcolm Barrie (editor) for is guidance and comments on the manuscript.

\section{References}

Basibuyuk, H.H., Quicke, D.L.J., Rasnitsyn, A.P., 2000. A new genus of the Orussidae (Insecta: Hymenoptera) from Late Cretaceous New Jersey amber. In: Grimaldi, D.A. (Ed.), Studies on 
Fossils in Amber, with Particular Reference to the Cretaceous of New Jersey. Backhuys Publishers, Leiden: $305-311$.

Burke, H.E., 1917. Oryssus is parasitic. Proceedings of the Entomological Society of Washington $19,87-89$.

Cockerell, T.D.A., 1917. Insects in Burmese amber. Annals of the Entomological Society of America 10, 323-329. https://doi.org/10.1093/aesa/10.4.323

Cruickshank, R.D., Ko, K., 2003. Geology of an amber locality in the Hukawng Valley, northern Myanmar. Journal of Asian Earth Sciences 21, 441-455. https://doi.org/10.1016/ S1367-9120(02)00044-5

Engel, M.S., 2008. An orussid wood wasp in amber from the Dominican Republic (Hymenoptera: Orussidae). Transactions of the Kansas Academy of Science 111, 39-44. https://doi.org/ 10.1660/0022-8443(2008)111[39:AOWWIA]2.0.CO;2

Gerstaecker, C.E.A., 1867. Über die Gattung Oxybelus Latr. und die bei Berlin vorkommenden Arten derselben. Zeitschrift fur die Gesammten Naturwissenschaften 30, 1-96.

Goulet, H., Huber, J.T., 1993. Hymenoptera of the world: An identification guide to families. ed. Agriculture Canada, Ottawa, Ontario, 680 pp.

Grimaldi, D., Ross, A., 2017. Extraordinary lagerstätten in amber, with particular reference to the Cretaceous of Burma. In: Fraser, N.C., Sues, H.-D., (Eds.), Terrestrial conservation lagerstätten: Windows into the evolution of life on land. Dunedin Academic Press, Edinburgh: 287-342.

Jouault, C., Pouillon, J.-M., Nel, A., 2020a. The first fossil horntail wasp (Hymenoptera: Siricidae) from Lower Cretaceous Crato Formation in Brazil. Palaeoentomology 3, 382-389. https:// doi.org/10.11646/palaeoentomology.3.4.10

Jouault, C., Rasnitsyn, A.P., Perrichot, V., 2020b. Ohlhoffiidae, a new Cretaceous family of basal parasitic wasps (Hymenoptera: Stephanoidea). Cretaceous Research 117, 104635. https://doi.org/ 10.1016/j.cretres.2020.104635 
Konow, F.W., 1897. Über fossile Blatt und Halmwespen. Entomologische Nachrichten 23, 36-38.

Kopylov, D.S., 2014. New sawflies of the subfamily Madygellinae (Hymenoptera, Xyelidae) from the Middle-Upper Triassic of Kyrgyzstan. Paleontological Journal 48, 610-620. https://doi.org/ $10.1134 / \mathrm{S} 0031030114060070$

Kopylov, D.S., Rasnitsyn, A.P., 2016. Cephidae (Hymenoptera) of the Mesozoic. Euroasian Entomological Journal 15, 78-83.

Latreille, P.A., 1796. Précis des caractères génériques des insectes, disposés dans un ordre naturel, Prévôt, Paris, 238 pp. https://doi.org/10.5962/bhl.title.58411

Leach, W.E., 1815. Entomology. In: Brewster, D. (Ed.): The Edinburgh Encyclopaedia, 9, 57-172.

Lin, M.Y., Bai, M., 2017. Qitianniu zhihaoi gen. et sp. nov.: The first cerambycid beetle found in Cretaceous Burmese amber (Coleoptera: Chrysomeloidea). Cretaceous Research 75, 173-178. https://doi.org/10.1016/j.cretres.2017.03.030

Linnaeus, C. von, 1758. Systema Naturae per regna tria naturae secundum classes, ordines, genera, species cum characteribus, differentiis, synonymis, locis. Ed. decima reformata. Holmiae, Laur. Salvii, 1, 1-823.

Ma, Y., Zheng, B.Y., Zhu, J.C., van Achterberg, C., Tang, P., Chen, X.X., 2019. The first two mitochondrial genomes of wood wasps (Hymenoptera: Symphyta): novel gene rearrangements and higher-level phylogeny of the basal hymenopterans. International Journal of Biological Macromolecules 123, 1189-1196. https://doi.org/10.1016/j.ijbiomac.2018.11.017

Martynov, A.V., 1925. To the knowledge of fossil insects from Jurassic beds in Turkestan. 3. Hymenoptera, Mecoptera. Izvestiya Akademii Nauk SSSR 19, 753-762.

Nel, A., 1997. The probabilistic inference of unknown data in phylogenetic analysis. In: Grandcolas, P. (Ed.). The origin of biodiversity in insects: phylogenetic tests of evolutionary scenarios. Mémoires du Muséum National d'Histoire Naturelle, Paris 173, 305-327. 
Nel, A., Petrulevicius, J.F., Henrotay, M. 2004. New Early Jurassic sawflies from Luxembourg: the oldest record of Tenthredinoidea (Hymenoptera: "Symphyta"). Acta Palaeontologica Polonica 49, 283-288. http://app.pan.pl/acta48/app49\%E2\%88\%92283.pdf

Nel, A., Roques, P., Nel, P., Prokin, A.A., Bourgoin, T., Prokop, J., Szwedo, J., Azar, D., DesutterGrandcolas, L., Wappler, T., Garrouste, R., Coty, D., Huang, Diying, Engel, M., Kirejtshuk, A.G., 2013. The earliest known holometabolous insects. Nature 503, 257-261. https://doi.org/ 10.1038 /nature 12629

Newman, E., 1834. Art. XXXVII. - Attempted division of British insects into natural orders. Entomological Magazine 2, 379-431.

Nutall, M.J., 1980. Insect parasites of Sirex. Forest and timber insects in New Zealand 47. Available at https://www.nzffa.org.nz/farm-forestry-model/the-essentials/forest-health-pests-and-diseases/ Pests/Sirex-noctilio/Insect-parasites-of-sirexEnt47/

Oyama, N., Maeda, H., 2020. Madygella humioi sp. nov. from the Upper Triassic Mine Group, southwest Japan: the oldest record of a sawfly (Hymenoptera: Symphyta) in East Asia. Paleontological Research 24, 64-71. https://doi.org/10.2517/2019PR005

Peters, R., Krogmann, L., Mayer, C., Donath, A., Gunkel, S., Meusemann, K., Kozlov, A., Podsiadlowski, L., Petersen, M., Lanfear, R., Diez, P., Heraty, J., Kjer, K., Klopfstein, S., Meier, R., Polidori, C., Schmitt, T., Liu, S., Zhou, X., Niehuis, O., 2017. Evolutionary history of the Hymenoptera. Current Biology 27, 1013-1018. https://doi.org/10.1016/j.cub.2017.01.027

Powell, J.A., Turner, W.J., 1975. Observations on oviposition behaviour and host selection in Orussus occidentalis (Hymenoptera: Siricoidea). Journal of the Kansas Entomological Society 48, 299-307. https://www.jstor.org/stable/25082758

Rasnitsyn, A.P., 1964. Novye Triasovye pereponchatokrylye sredney Azii [New Triassic Hymenoptera from Central Asia]. Paleontologicheskii Zhurnal 1964, 88-96. 
Rasnitsyn, A.P., 1968. Noviye Mezozoyskiye Pilil'shchiki (Hymenoptera, Symphata) [New Mesozoic sawflies (Hymenoptera, Symphyta)]. Yurskoy Nasekomiye Karatau [Jurassic Insects of Karatau] 190-236.

Rasnitsyn, A.P., 1969. Proiskhozhdenie i evolyutsiya nizshikh pereponchatokrylykh [The origin and evolution of lower Hymenoptera.] Trudy Paleontologicheskogo Instituta Akademii nauk SSSR 123, 1-196. [in Russian, English translation: Origin and Evolution of Lower Hymenoptera. Amerind Co., New Dehli, 1979].

Rasnitsyn, A.P., 1977. New Hymenoptera from the Jurassic and Cretaceous of Asia. Paleontological Journal 11, 349-357.

Rasnitsyn, A.P., Zhang, H.C., 2010. Early evolution of Apocrita (Insecta, Hymenoptera) as indicated by new findings in the Middle Jurassic of Daohugou, Northeast China. Acta Geologica Sinica 84, 834-873. https://doi.org/10.1111/j.1755-6724.2010.00254.x

Rawlings, G.B., 1957. Guiglia schauinslandi (Ashmead) (Hym. Orussidae) a parasite of Sirex noctilio (Fabricius) in New Zealand. The Entomologist 90, 35-36.

Ronquist, F., Klopfstein, S., Vilhelmsen, L., Schulmeister, S., Murray, D.L., Rasnitsyn, A.P., 2012. A total-evidence approach to dating with fossils, applied to the early radiation of the Hymenoptera. Systematic Biology 61, 973-999. https://doi.org/10.1093/sysbio/sys058

Ronquist, F., Rasnitsyn, A.P., Roy, A., Erikson, K., Lindgren, M., 1999. Phylogeny of the Hymenoptera: a cladistic reanalysis of Rasnitsyn's (1988) data. Zoologica Scripta 28, 13-50. https:// doi.org/10.1046/j.1463-6409.1999.00023.x

Schedl, W., 2011. Eine Orussidae aus dem baltischen Bernstein (Hymenoptera: Symphyta). Zeitschrift der Arbeitsgemeinschaft Österreichischer Entomologen 63, 33-36.

Shi, G.H., Grimaldi, D.A., Harlow, G.E., Wang, J., Wang, J., Yang, M.C., Lei, W.Y., Li, Q.L., Li, X.H., 2012. Age constraint on Burmese amber based on U-Pb dating of zircons. Cretaceous Research 37, 155-163. https://doi.org/10.1016/j.cretres.2012.03.014 
Taeger, A., Blank, S.M., Liston, A.D., 2010. World catalog of Symphyta (Hymenoptera). Zootaxa, 2580, 1-1064. https://doi.org/10.11646/zootaxa.2580.1.1

Vilhelmsen, L., 2001. Phylogeny and classification of the extant basal lineages of the Hymenoptera (Insecta). Zoological Journal of the Linnean Society 131, 393-442. https://doi.org/10.1111/ j.1096-3642.2001.tb01320.x

Vilhelmsen, L., 2003. Phylogeny and classification of the Orussidae (Insecta: Hymenoptera), a basal parasitic wasp taxon. Zoological Journal of the Linnean Society 139, 337-418. https:// doi.org/10.1046/j.1096-3642.2003.00080.x

Vilhelmsen, L., 2004. The old wasp and the tree: fossils, phylogeny and biogeography in the Orussidae (Insecta, Hymenoptera). Biological Journal of the Linnean Society 82, 139-160. https:// doi.org/10.1111/j.1095-8312.2004.00327.x

Vilhelmsen, L., 2016. A new species of Ophrella Middlekauff, 1985 (Hymenoptera, Orussidae) from French Guiana. Journal of Hymenoptera Research 51, 171-185. https://doi.org/10.3897/ jhr.51.9075

Vilhelmsen, L. (2020) From hairpin to safety pin: evolution of the ovipositor apparatus in Orussidae (Insecta: Hymenoptera). Zoomorphology 139, 37-49. https://doi.org/10.1007/ s00435-019-00468-y

Vilhelmsen, L., Blank, S.M., Sechi, D., Ndiaye, M.M., Niang, A.A., Guisse, A., Van Noort, S., 2017. The Orussidae (Insecta: Hymenoptera) of Africa. Proceedings of the Entomological Society of Washington 119, 879-930. https://doi.org/10.4289/0013-8797.119.SpecialIssue.879

Vilhelmsen, L., Isidoro, N., Romani, R., Basibuyuk, H.H., Quicke, D.L.J., 2001. Host location and oviposition in a basal group of parasitic wasps: the subgenual organ, ovipositor apparatus, and associated structures in the Orussidae (Hymenoptera, Insecta). Zoomorphology 121, 63-84. https://doi.org/10.1007/s004350100046 
Vilhelmsen, L., Turrisi, G.F., 2011. Per arborem ad astra: morphological adaptations to exploiting the woody habitat in the early evolution of Hymenoptera. Arthropod Structure \& Development 40, 2-20. https://doi.org/10.1016/j.asd.2010.10.001

Vilhelmsen, L., Turrisi, G.F., Beutel, R.G., 2008. Distal leg morphology, subgenual organs and host detection in Stephanidae (Insecta, Hymenoptera). Journal of Natural History 42, 1649-1663. https://doi.org/10.1080/00222930802105155

Vilhelmsen ,L., Zimmermann, D., 2014. Baltorussus total makeover: Rejuvenation and sex change in an ancient parasitoid wasp lineage. PLOS ONE 9, e98412. https://doi.org/10.1371/journal.pone.0098412

Wang, M., Rasnitsyn, A.P., Li, Hu, Shih, Chungkun, Sharkey, M.J., Ren, D. (2016). Phylogenetic analyses elucidate the inter-relationships of Pamphilioidea (Hymenoptera, Symphyta). Cladistics 32, 239-260. https://doi.org/10.1111/cla.12129

Wang, Y., Wang, M., Rasnitsyn, A.P., Shih, C., Ren, D., Kopylov, D., Gao, T., 2020. A new anaxyelid sawfly (Insecta, Hymenoptera, Siricoidea) in mid-Cretaceous Myanmar amber. Cretaceous Research 109, 104372. https://doi.org/10.1016/j.cretres.2020.104372

Yu, T., Kelly, R., Mu, L., Ross, A., Kennedy, J., Broly, P., Xia, F., Zhang, H., Wang, B., Dilcher, D. (2019) An ammonite trapped in Burmese amber. Proceedings of the National Academy of Sciences of the United States of America 116, 11345-11350. https://doi.org/10.1073/ pnas. 1821292116

Zhang, Q., Kopylov, D.S., Rasnitsyn, A.P., Zheng, Y., Zhang., H., 2020. Burmorussidae, a new family of parasitic wasps (Insecta, Hymenoptera) from mid-Cretaceous Burmese amber. Papers in Palaeontology 6, 593-603. https://doi.org/10.1002/spp2.1312

Table and figure captions:

Table 1: Diversity of fossil Orussoidea. 


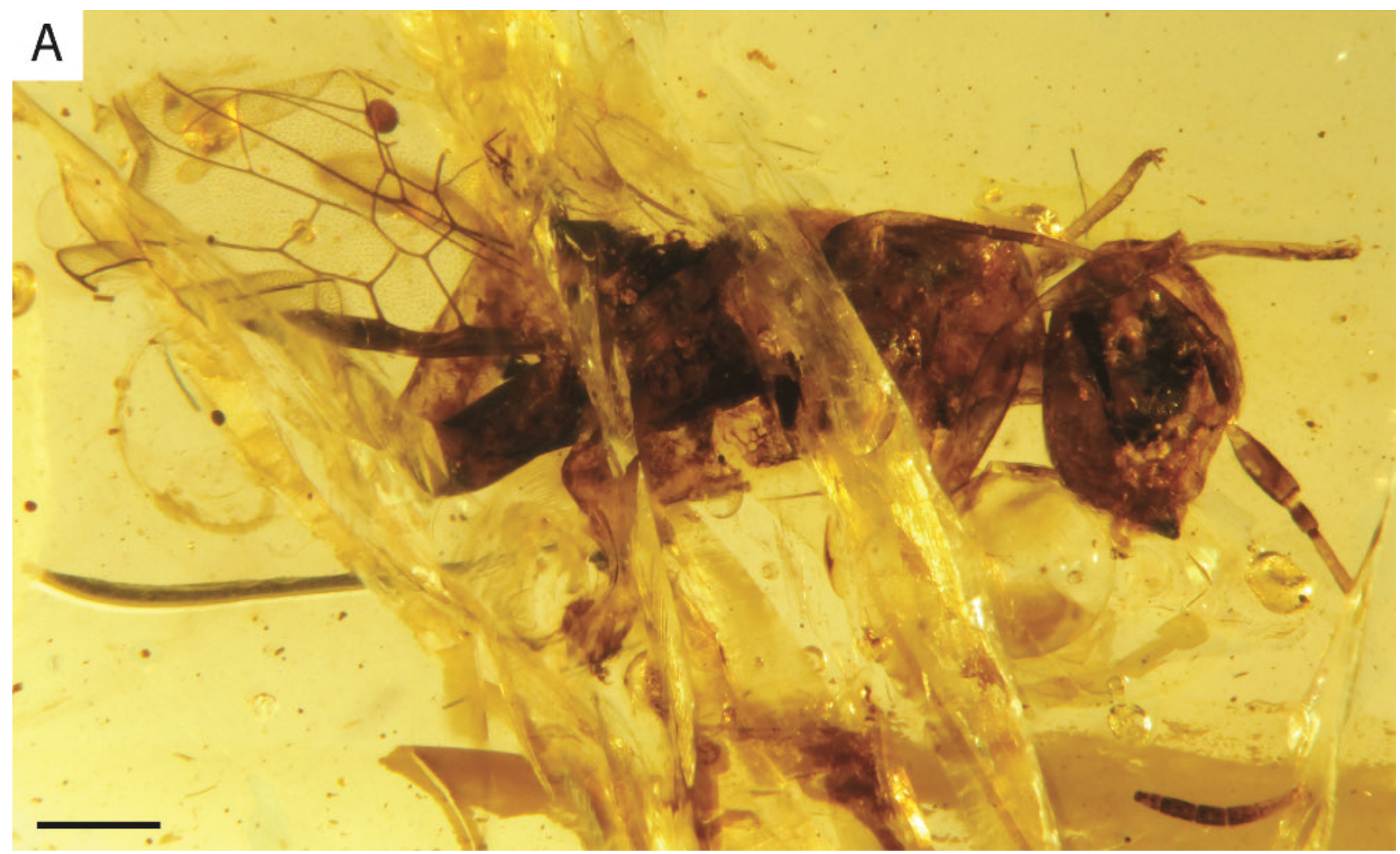

Figure 1. Cretorussus vilhelmseni gen. et sp. nov., holotype IGR.BU-020. Photographs of habitus, right lateral view. Scale bar: $0.5 \mathrm{~mm}$. 

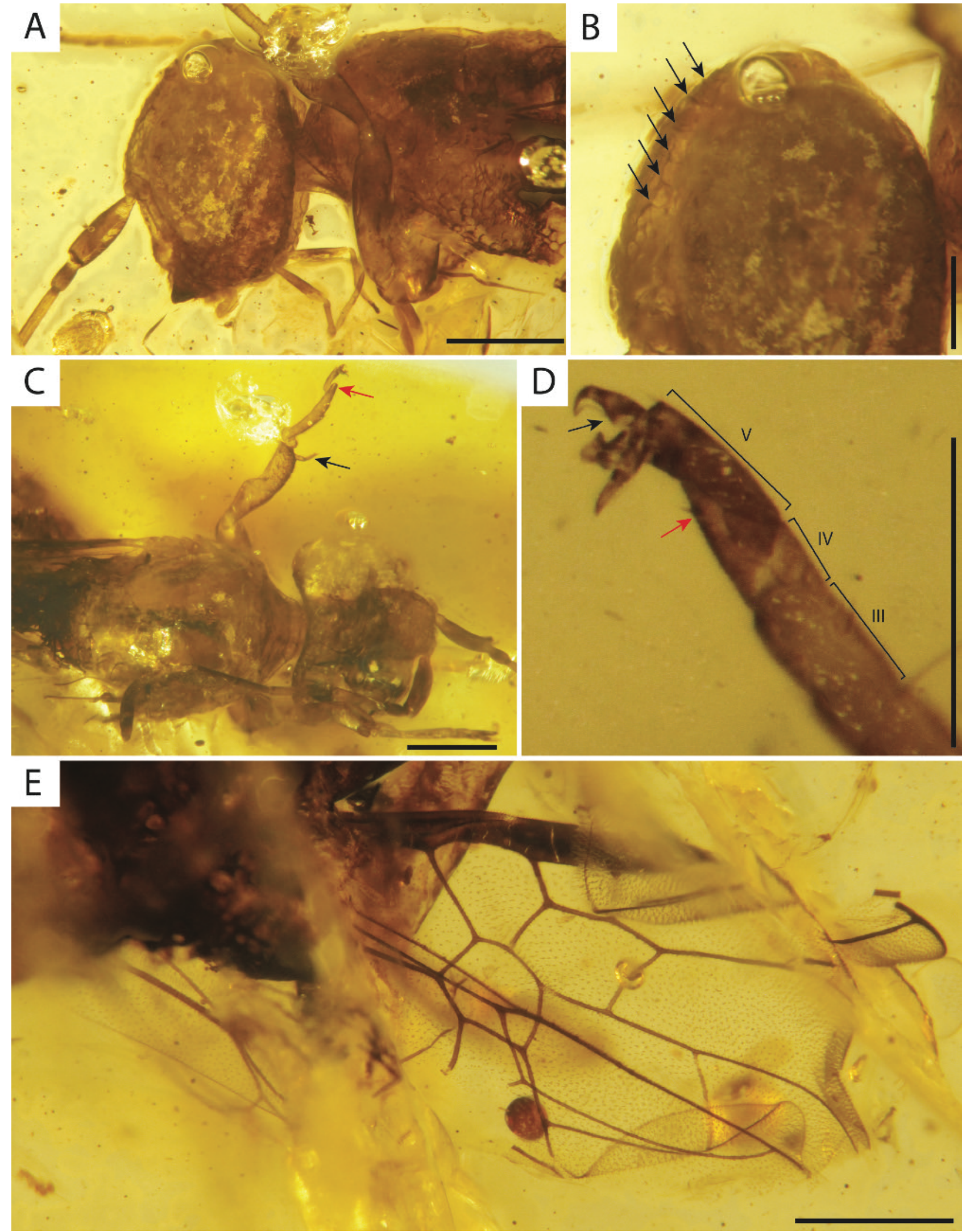

Figure 2. Cretorussus vilhelmseni gen. et sp. nov., holotype IGR.BU-020. A: head and thorax in lateral view. B: vertex (arrows pointing ocellar corona and tubercles). C: head and thorax in dorsal view (black arrow pointing bifid spurs; red arrow pointing modified tarsomere). D: apical part of 
pro-tarsus (arrow pointing the modified tarsomere). E: wings. Scale bars: $0.5 \mathrm{~mm}$ (A, C, E); 0.25 $\mathrm{mm}(\mathrm{B}, \mathrm{D})$.

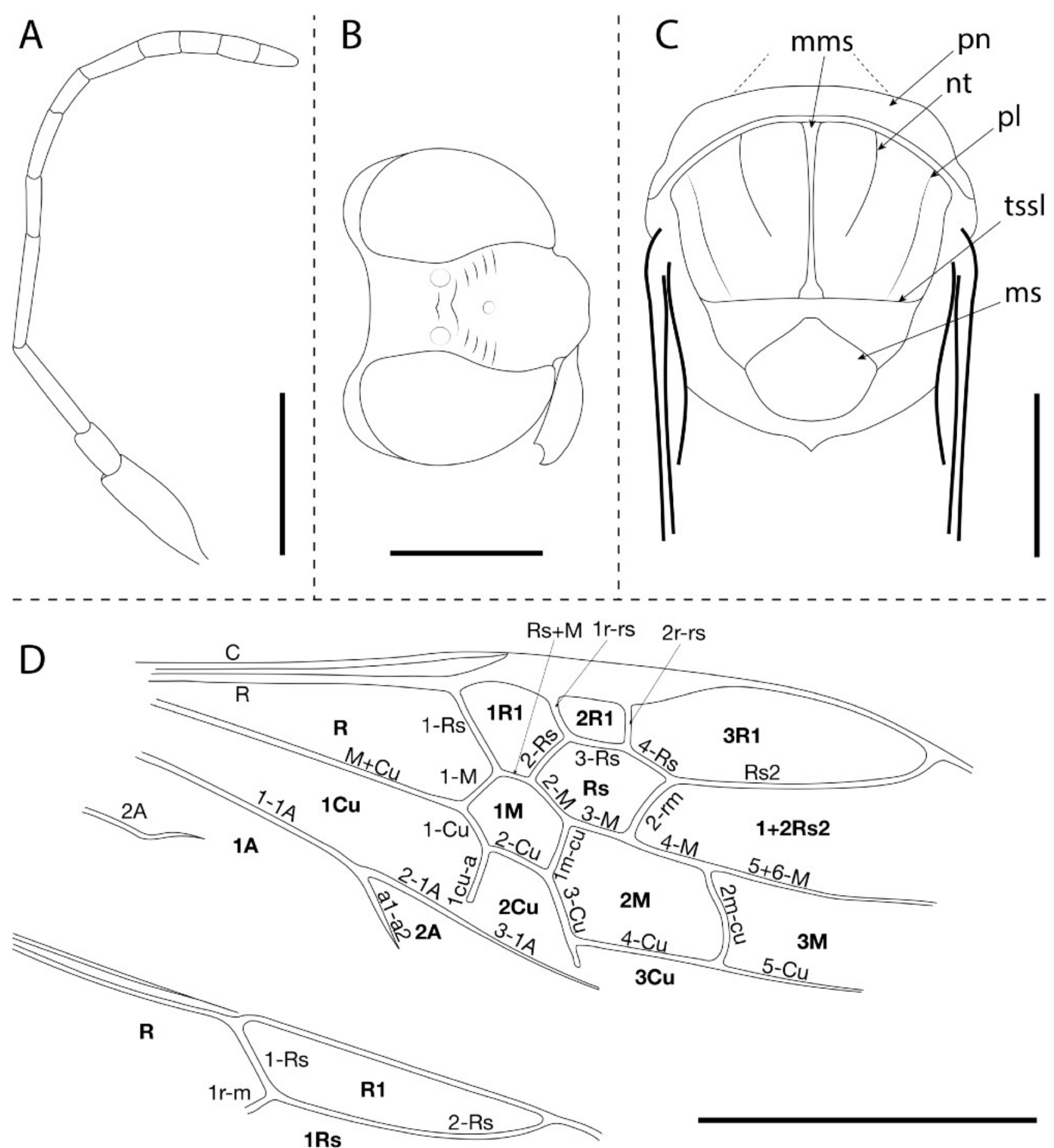


Figure 3. Cretorussus vilhelmseni gen. et sp. nov., holotype IGR.BU-020. A: line drawing of antenna. B: interpretative drawing of head in dorsal view. C: line drawing of thorax in dorsal view. D: reconstruction of wings (cell names in bold). $\mathrm{mms}=$ median mesoscutal sulcus; $\mathrm{pn}=$ pronotum; $\mathrm{nt}=$ notauli; $\mathrm{pl}=$ parapsidal lines; tssl $=$ transscutal line; $\mathrm{ms}=$ mesoscutellum. Scale bars $=0.5$ mm (A, B, C); $1 \mathrm{~mm}(\mathrm{D})$.

\begin{tabular}{|c|c|c|c|c|c|}
\hline Families / Genera & Specios & Distribution & Period & Locality / Formation & \\
\hline \multicolumn{6}{|l|}{ Burmorussidea } \\
\hline Burmorussus Zhang, Kopylov \& Rasnitsyn, 2020 & B. mirabilis Zhang, Kopylov \& Rasnitsyn, 2020 & Myanmar & late Albian- early Cenomanian & Burmese amber & Zhang et al., 2020 \\
\hline Cretorussus gen. nov. & C. vilheimseni gen. et sp. nov. & Myanmar & late Albian- early Cenomanian & Burmese amber & This study \\
\hline \multicolumn{6}{|l|}{ Orussidae } \\
\hline Baltorussus Schedl, 2011 & B. velteni Schedl, 2011 & Russia & Priabonian & Baltic amber & $\begin{array}{l}\text { Schedl, } 2011 \\
\text { Viheimsen \& } \\
\text { Zimmermann, } 2014\end{array}$ \\
\hline Minyorussus Basibuyuk et al., 2000 & M. Iuzzii Basibuyuk et al., 2000 & USA & Turonian & New Jersey amber & Basibuyuk et al., 2000 \\
\hline Ophrynopus Konow, 1897 & O. peritus Engel, 2008 & Dominican Republic & Burdigalian to Serravallian & Dominican amber & $\begin{array}{l}\text { Konow, } 1897 \\
\text { Engel, } 2008\end{array}$ \\
\hline \multicolumn{6}{|l|}{ Mesorussinae } \\
\hline Mesorussus Rasnitsyn, 1977 & M. taimyrensis Rasnitsyn, 1977 & Russia & Cenomanian & Taimyr amber & Rasnitsyn, 1977 \\
\hline \multicolumn{6}{|l|}{ Paroryssidae Martynov, 1925} \\
\hline \multirow[t]{6}{*}{ Microryssus Rasnitsyn, 1968} & M. antennatus Rasnitsyn, 1968 & Kazakhstan & Callovian / Oxfordian & Karatau-Mikhailovka / Karabastau Formation & Rasnitsyn, 1968 \\
\hline & M. brachyurus Rasnitsyn, 1968 & Kazakhstan & Callovian / Oxfordian & Karatau-Mikhailovka / Karabastau Formation & Rasnitsyn, 1968 \\
\hline & M. crassipes Rasnitsyn, 1968 & Kazakhstan & Callovian / Oxfordian & Karatau-Mikhailovka / Karabastau Formation & Rasnitsyn, 1968 \\
\hline & M. minus Rasnitsyn, 1968 & Kazakhstan & Callovian / Oxfordian & Karatau-Mikhailovka / Karabastau Formation & Rasnitsyn, 1968 \\
\hline & M. robustus Rasnitsyn, 1968 & Kazakhstan & Callovian / Oxfordian & Karatau-Mikhailovka / Karabastau Formation & Rasnitsyn, 1968 \\
\hline & M. subtilis Rasnitsyn, 1968 & Kazakhstan & Callovian / Oxfordian & Karatau-Mikhailovka / Karabastau Formation & Rasnitsyn, 1968 \\
\hline Paroryssus Martynov, 1925 & P. extensus Martynov, 1925 & Kazakhstan & Callovian / Oxfordian & Karatau-Galkino / Karabastau Formation & Martynov, 1925 \\
\hline \multirow[t]{2}{*}{ Praeoryssus Rasnitsyn, 1968} & P. gracilis Rasnitsyn, 1968 & Kazakhstan & Callovian / Oxfordian & Karatau-Mikhailovka / Karabastau Formation & Rasnitsyn, 1968 \\
\hline & P. venosus Rasnitsyn, 1968 & Kazakhstan & Callovian / Oxfordian & Karatau-Mikhailovka / Karabastau Formation & Rasnitsyn, 1968 \\
\hline
\end{tabular}

